\title{
Mustard Seeds in Ayurvedic Medicine
}

\author{
Nida Tabassum Khan* \\ Department of Biotechnology, Pakistan
}

*Corresponding author: Nida Tabassum Khan, Department of Biotechnology, Faculty of Life Sciences and Informatics, Quetta, Pakistan

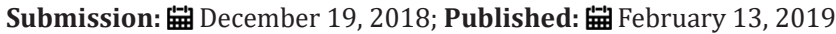

\begin{abstract}
Mustard seeds commonly called as Rai, Sarso etc is scientifically known by the name of Brassica Juncea. Different varieties of mustard seeds have been cultivated in countries like Asia, India, United States, Eastern Meditarrian, Hungary, Britain, Europe, Greece, Rome, Canada and in the Middle East. Besides being used in culinary it was once considered as an important natural remedy for gastric discomforts. With the passage of time numerous health benefits of mustard seeds have been explored which will be valuable for the development of novel drugs.

Keywords: Oxalates; Goitrogens; Respiratory congestion; Selenium; Omega fatty acids
\end{abstract}

\section{Introduction}

Mustard seeds commonly called as Rai, Sarso, Shorshe, Kadugu in different languages is scientifically known by the name of Brassica juncea of the family Brassicaceae [1]. Different varieties of mustard seeds such as Brassica alba (White), Brassica juncea (brown) and Brassica nigra (black), seeds are extensively cultivated in countries like Asia, India, United States, Eastern Meditarrian, Hungary, Britain,
Europe, Greece, Rome, Canada and in the Middle East where it is used in cooking for its sharp aroma and in traditional medicine $[2,3]$. Mustard seeds were once considered as an important natural remedy for relieving stomach distress such as flatulence or cramps [4-24]. With recent studies multitude of its medicinal potential was explored which is briefly outlined in the table below (Table 1 ).

Table 1

\begin{tabular}{|c|c|c|}
\hline S.no & Medicinal Potential & \\
\hline 1 & Inhibits cancer formation & $\begin{array}{l}\text { Presence of selenium, mirosinase, glucosinolates etc impedes cancer cell growth and } \\
\text { development and acts as an anti-oxidant [5] }\end{array}$ \\
\hline 2 & $\begin{array}{l}\text { Treatment of Rheumatic Arthritis and } \\
\text { Migraine }\end{array}$ & $\begin{array}{c}\text { Magnesium and selenium content aids in providing relief from its associated symptoms } \\
{[6]}\end{array}$ \\
\hline 3 & Treatment of Respiratory Congestion & $\begin{array}{l}\text { It clears the mucus in the respiratory tract to treat bronchitis/asthma and promotes } \\
\text { easy breathing [7]. }\end{array}$ \\
\hline 4 & Treatment of Constipation & Aids in easy bowel movements to keep the colon healthy [8]. \\
\hline 5 & $\begin{array}{l}\text { Treatment of High Blood Pressure and } \\
\text { Menopausal associated problems }\end{array}$ & $\begin{array}{l}\text { Copper, magnesium, iron, and selenium in mustard seeds reduces high blood pressure } \\
\text { and conditions like osteoporosis in menopausal women }[9,10] \text {. }\end{array}$ \\
\hline 6 & Treatment of Dermal problems & $\begin{array}{c}\text { Carotene, vitamins, sulphur and lutein in mustard seeds exhibits antioxidant and } \\
\text { antifungal property therefore use as a natural scrub to hydrate skin and fight off fungal } \\
\text { infections from the skin }[11,12]\end{array}$ \\
\hline 7 & Treatment of Hair problems & $\begin{array}{l}\text { Mustard seed oil is an excellent source of vitamins, proteins and fattyacids which is } \\
\text { required for healthy hair growth and reduces hair fall [13] }\end{array}$ \\
\hline 8 & Treats Back Pain & It also helps in relieving spasms, backbone pain and other muscular aches [14] \\
\hline
\end{tabular}




\begin{tabular}{|c|c|c|}
\hline 9 & Treatment of Cold/fever & Relieve congestion and aids in removal of toxins from the body [15] \\
\hline 10 & Develops Cardiovascular Health & $\begin{array}{l}\text { Alleviates chest pain, cardiac arrhythmia rate, risk of thrombosis, arterial blockages, } \\
\text { high cholesterol level and ventricular enlargement due to the presence of omega fatty } \\
\text { acids in mustard seeds [16-18] }\end{array}$ \\
\hline 11 & Poison Repulsion & Mustard seeds aids in cleansing the body especially from alcohol, narcotics etc [19] \\
\hline 12 & Treats Ringworm & Effective in treating ringworm associated lesions [20] \\
\hline 13 & Healing Effect on Nerves & Reduce nerve damage by stimulating nerve impulses to initiate healing effect [21] \\
\hline 14 & Treatment of Diabetes & $\begin{array}{l}\text { It neutralizes the effect of free radicals to protect against oxidative stress. It also lowers } \\
\text { lipid peroxidation, level of glycosylated proteins and glucose in the serum to stimulate } \\
\text { glucose metabolism }[22,23]\end{array}$ \\
\hline 15 & Treatment of Gastric Discomforts & $\begin{array}{l}\text { Presence of myrosinase enzyme in mustard seed breaks down glucosinolates in to } \\
\text { isothiocyanate which exhibits anticancer property and lowers the risk of colorectal and } \\
\text { gastrointestinal tract cancer formation [24] }\end{array}$ \\
\hline
\end{tabular}

\section{Storage of mustard seeds}

Mustard seeds either whole or grounded form can easily be stored in a dry airtight jar for approximately six to eight months [25].

\section{Side effects of over consumption of mustard seeds}

Over consumption of mustard seeds might result in the following side effects:

A. Development of allergic reactions such as hypersensitivity [26].

\section{B. Skin irritation [27]}

C. Raw mustard seeds contain goitrogens, a compound which interferes with the normal functioning of thyroid gland [28]

D. Presence of oxalates in mustard seeds interfere with the normal absorption of calcium in the body. Therefore, could be problematic for kidney stones patients [29].

\section{Conclusion}

Thus, mustard seeds possess numerous therapeutic agents that could be used for the treatment of number of health-related problems.

\section{References}

1. Singh D (1958) Rape and mustard. Department of Agriculture; Uttar Pradesh, India.

2. Manohar P, Pushpan R, Rohini S (2009) Mustard and its uses in Ayurveda. Indian Journal of Traditional Knowledge 8(3): 400-404.

3. Rakow G (2004) Species origin and economic importance of Brassica. Brassica, pp. 3-11.

4. Aruna G, Baskaran V (2010) Comparative study on the levels of carotenoids lutein, zeaxanthin and $\beta$-carotene in Indian spices of nutritional and medicinal importance. Food Chemistry 123(2): 404-409.
5. Dragland S, Senoo H, Wake K, Holte K, Blom hoff R (2003) Several culinary and medicinal herbs are important sources of dietary antioxidants. Journal Nutr 133(5): 1286-1290.

6. Sreekeesoon DP, Mahomoodally MF (2014) Ethnopharmacological analysis of medicinal plants and animals used in the treatment and management of pain in Mauritius. Journal of Ethnopharmacology 157: 181-200.

7. Shah B, Sheth F, Parabia M (2012) Folk herbal knowledge on the management of respiratory disorders prevailing in ethnic society of Valsad district, Gujarat, India.

8. Lavanya B, Ramya PS, Nagarjuna S, Reddy YP (2011) In-vitro comparative study of anthelmintic activity of Brassica juncea and Brassica oleracea. J Pharm Res 4(9): 2907-2909.

9. Iyer A, Panchal S, Poudyal H, Brown L (2009) Potential health benefits of Indian spices in the symptoms of the metabolic syndrome: a review. Indian J Biochem Biophys 46(6): 467-481.

10. Hashmi SI, Satwadhar PN, Khotpal RR, Deshpande HW, Syed KA, et al. (2016) Rapeseed meal nutraceuticals. Journal of Oilseed Brassica 1(2): 43-54

11. Zhu YG, Pilon EA, Zhao FJ, Williams PN, Meharg AA (2009) Selenium in higher plants: understanding mechanisms for biofortification and phytoremediation. Trends in plant science 14(8): 436-442.

12. Ahmad I, Mehmood Z, Mohammad F (1998) Screening of some Indian medicinal plants for their antimicrobial properties. Journal of ethnopharmacology 62(2): 183-193.

13. Lourith N, Kanlayavattanakul M (2013) Hair loss and herbs for treatment. J Cosmet Dermatol 12(3): 210-222.

14. Wirth JH, Hudgins JC, Paice JA (2005) Use of herbal therapies to relieve pain: A review of efficacy and adverse effects. Pain Manag Nurs 6(4): 145-167.

15. Weng W, Chen J (1996) The eastern perspective on functional foods based on traditional Chinese medicine. Nutrition Reviews 54(11): S11-S16.

16. Iyer A, Panchal S, Poudyal H, Brown L (2009) Potential health benefits of Indian spices in the symptoms of the metabolic syndrome: a review. Indian J Biochem Biophys 46(6): 467-481. 
17. Vasanthi H, Parameswari R (2010) Indian spices for healthy heart-an overview. Curr Cardiol Rev 6(4): 274-279.

18. Srinivasan K (2005) Role of spices beyond food flavoring: Nutraceuticals with multiple health effects. Food Reviews International 21(2): 167-188.

19. Manchester LC, Tan DX, Reiter RJ, Park W, Monis K, et al. (2000) High levels of melatonin in the seeds of edible plants: possible function in germ tissue protection. Life Sciences 67(25): 3023-3029.

20. Chitwood D J (2002) Phytochemical based strategies for nematode control. Annu Rev Phytopathol 40(1): 221-249.

21. Jordt SE, Bautista DM, Chuang HH, McKemy DD, Zygmunt PM, et al (2004) Mustard oils and cannabinoids excite sensory nerve fibres through the TRP channel ANKTM1. Nature 427(6971): 260-265.

22. Jaradat NA (2005) Medical plants utilized in Palestinian folk medicine for treatment of diabetes mellitus and cardiac diseases. J Al-Aqsa Unv 9: 1-28.

23. Grover JK, Yadav S, Vats V (2002) Medicinal plants of India with antidiabetic potential. Journal of Ethnopharmacology 81(1): 81-100.
24. Peter KV, Babu KN (2012) Introduction to herbs and spices: medicinal uses and sustainable production. In: Handbook of Herbs and Spices $\left(2^{\text {nd }}\right.$ edn), 2: 1-16.

25. Harrington JF (1972) Seed storage and longevity. Seed Biology 3: 145245.

26. Burks AW, Tang M, Sicherer S, Muraro A, Eigenmann PA, et al. (2012) ICON: food allergy. Journal of Allergy and Clinical Immunology 129(4): 906-920.

27. Dalal I, Binson I, Reifen R, Amitai Z, Shohat T, et al. (2002) Food allergy is a matter of geography after all: sesame as a major cause of severe IgEmediated food allergic reactions among infants and young children in Israel. Allergy 57(4): 362-365.

28. Bell JM (1984) Nutrients and toxicants in rapeseed meal: a review. J Anim Sci 58(4): 996-1010.

29. Ravindran V, Blair R (1992) Feed resources for poultry production in Asia and the Pacific. II Plant protein sources. World's Poultry Science Journal 48(3): 205-231.
Creative Commons Attribution 4.0

International License

For possible submissions Click Here

\section{Submit Article}

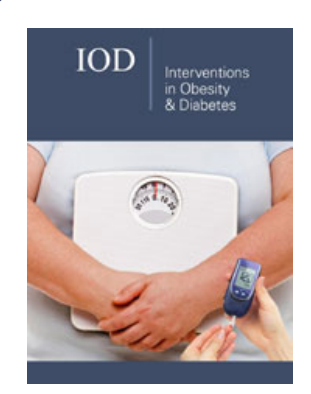

\section{Intervention in Obesity \& Diabetes}

Benefits of Publishing with us

- High-level peer review and editorial services

- Freely accessible online immediately upon publication

- Authors retain the copyright to their work

- Licensing it under a Creative Commons license

- Visibility through different online platforms 